\title{
HUBUNGAN LOCUS OF CONTROL DAN PERSEPSI PERAN JENIS KELAMIN DENGAN KEPUTUSAN PEMILIHAN KARIER SISWA KELAS $X$ SMA NEGERI 6 SEMARANG
}

\section{Tyas Martika Anggriana}

Penelitian ini bertujuan untuk mengetahui pengaruh locus of control dan persepsi peran jenis kelamin terhadap keputusan pemilihan karier siswa SMA Negeri 6 Semarang.

Penelitian ini adalah penelitian expost-facto dengan menggunakan pendekatan kuantitatif nonekperimental. Pengujian validitas alat ukur menggunakan analisis rasional atau professional judgement dan perhitungan validitas konstruk menggunakan uji Product Moment. Estimasi reliabilitas diukur dengan menggunakan koefisien reliabilitas Alpha. Penelitian ini mengambil sampel dari sebagian siswa kelas X SMA Negeri 6 Semarang dengan jumlah sampel 186 siswa menggunakan teknik cluster random sampling. Uji hipotesis dilakukan dengan menggunakan analisis regresi.

Berdasarkan uji hipotesis diperoleh hasil terdapat hubungan locus of control dan persepsi peran jenis kelamin terhadap keputusan pemilihan karier siswa. Analisis tambahan dengan menggunakan uji crosstabulation (Chi-Square) diperoleh hasil tidak terdapat perbedaan pemilihan karier siswa yang memiliki internal locus of control dan external locus of control, namun terdapat perbedaan pemilihan karier siswa dengan peran jenis maskulin, feminin, androgini, dan undifferentiated.

Kata kunci: keputusan pemilihan karier, locus of control, persepsi peran jenis kelamin 


\section{Pendahuluan}

Pengambilan keputusan karier bukanlah peristiwa sesaat, melainkan proses yang panjang dan merupakan bagian dari perkembangan individu. Pengambilan keputusan karier yang sesuai dengan kemampuan bagi siswa bukan hal yang mudah untuk ditentukan. Penentuan tersebut harus didasarkan pada keputusan siswa sendiri yang didasarkan pada pemahaman tentang kemampuan dan minat serta pengenalan karier yang ada di masyarakat.

Pada usia remaja akhir, siswa diharapkan mampu membuat keputusan secara tepat tanpa mengandalkan diri pada orang dewasa, membuat persiapan untuk kehidupan orang dewasa, sudah bisa memilih tujuan vokasional tertentu dan mengembangkan keterampilan vokasional yang diperlukan, bekerja sambilan, tamat SMA kemudian bekerja atau melanjutkan pendidikan (Munandir, 1996: 88). Jika seorang siswa gagal menunaikan suatu tugas perkembangan pada tahap tertentu, maka kemungkinannya siswa akan menjumpai kesulitan, terhalang dalam menunaikan tugas-tugas dalam tahap-tahap perkembangan berikutnya. Di bidang pekerjaan, jika pada suatu tahap perkembangannya seorang siswa yang memasuki usia remaja tidak mempunyai pengetahuan tentang kerja atau belum mengembangkan sikap kerja yang dikehendaki maka akan sulit baginya jika kemudian bekerja untuk mencari nafkah.

Kenyataan yang terjadi adalah bahwa siswa SMA masih mengalami kebingungan dalam memilih arah karier untuk masa depannya. Kebanyakan dari siswa memilih suatu karier karena faktor pengaruh teman atau orang lain yang berada di sekitarnya, tanpa memperhatikan dan mempertimbangkan faktor internal dalam dirinya.

Hirschi dan Lage (2007: 185) menjelaskan hasil penelitiannya bahwa siswa yang usianya 12 - 16 tahun, pemilihan kariernya berada pada fase telah memilih bidang karier tertentu namun belum yakin dengan pilihannya. Berdasarkan pada perbedaan jenis kelamin antara laki-laki dan perempuan, dijelaskan bahwa siswa laki-laki memilih bidang karier tertentu berdasarkan pada bidang pekerjaan orang tuanya. Disisi lain, berdasarkan tingkat perkembangan fisik dan kognitif 
pada tingkat usianya, siswa laki-laki belum menunjukkan kesiapan dalam pemilihan karier dan belum memiliki rencana karier untuk masa depannya.

Hasil temuan pada siswa perempuan menunjukkan bahwa siswa perempuan lebih menghadapi kesulitan dalam pengambilan keputusan karier. Hal ini karena siswa perempuan menghadapi kemungkinan lebih dibatasi untuk memilih bidang karier kejuruan dalam bidang pekerjaan tradisional perempuan. Beberapa dari siswa perempuan juga merasakan potensi konflik antara peran masa depan sebagai ibu dan ibu rumah tangga dan kejuruan professional (Hirschi dan Lage, 2007: 185).

Kesulitan yang dialami siswa dalam memilih dan menentukan karier kemungkinan disebabkan banyak siswa yang kurang memahami bahwa karier merupakan jalan hidup dalam usaha menggapai kehidupan yang baik di masa mendatang. Faktor yang menyebabkan siswa kesulitan dalam pemilihan karier antara lain faktor yang ada dalam diri siswa (internal) dan faktor di luar siswa (eksternal).

Winkel (2007: 647) mengungkapkan faktor internal yang mempengaruhi pengambilan keputusan karier siswa adalah nilai-nilai kehidupan (values), taraf inteligensi, bakat khusus, minat, sifat/ciri kepribadian, dan pengetahuan. Faktor eksternal yang mempengaruhi pengambilan keputusan karier siswa adalah lingkungan sosial budaya tempat siswa dibesarkan, status sosial ekonomi keluarga, pengaruh keluarga, pendidikan sekolah, pergaulan dengan teman sebaya dan tuntutan yang melekat pada pekerjaan.

Locus of Control merupakan salah satu faktor prediktor internal dalam proses pemilihan karier siswa. Locus of Control menggambarkan seberapa jauh individu memandang hubungan antara perbuatan yang dilakukannya dengan akibat atau hasilnya. Jika dikaitkan dengan pemilihan karier, dapat diartikan seberapa jauh individu memberdayakan potensi dirinya agar dapat memperoleh hasil terbaik dalam proses pengambilan keputusan karier.

Siswa SMA yang mempunyai internal Locus of Control ketika di hadapkan dengan pemilihan karier, maka akan melakukan usaha untuk mengenali diri, mencari tahu tentang pekerjaan 
dan langkah-langkah pendidikan serta berusaha mengatasi masalah yang berkaitan dengan pemilihan karier. Jika siswa SMA memiliki external Locus of Control, maka siswa akan membuat keputusan pemilihan karier karena pengaruh teman, orang tua, keberhasilan teman dan tanpa memperhatikan kemampuannya sendiri.

Hasil penelitian yang dilakukan oleh Zulkaida, dkk (2007) mendapatkan hasil bahwa Locus of Control memiliki pengaruh yang signifikan terhadap kematangan karier siswa SMA karena adanya keyakinan akan kemampuan diri dalam memilih karier yang disertai dengan keyakinan bahwa seluruh peristiwa dalam hidupnya ditentukan oleh usaha dan perilakunya sendiri. Hal tersebut pada gilirannya akan mendorong individu untuk mengarahkan segala tenaga, usaha dan perilakunya untuk mencapai kematangan karier yang diharapkan, dimana kematangan karier akan tercapai jika individu dapat melakukan pemilihan karier dengan baik.

Faktor eksternal yang terkait di antaranya adalah kondisi sosial masyarakat, yaitu lingkungan sosial budaya dimana individu dibesarkan. Pandangan atau keyakinan ini mencakup gambaran tentang luhur rendahnya aneka jenis pekerjaan, peranan laki-laki dan perempuan dalam kehidupan masyarakat dan cocok tidaknya jabatan tertentu untuk laki-laki dan perempuan atau bisa disebut dengan persepsi peran jenis kelamin.

Hasil penelitian yang dilakukan oleh Correl (2001: 1691) menunjukkan bahwa keyakinan budaya tentang perbedaan persepsi gender mempengaruhi keputusan awal mengenai karier yang relevan bagi laki-laki dan perempuan. Keyakinan terhadap peran gender atau peran jenis akan menyebabkan perbedaan keputusan untuk memilih karier di bidang sains, matematika, atau bidang teknik.

Berdasarkan pada beberapa faktor yang mempengaruhi pemilihan karier siswa, pada penelitian ini akan lebih memperhatikan faktor Locus of Control yang dan persepsi terhadap peran jenis yang merupakan faktor internal karena kedua faktor tersebut memiliki hubungan yang cukup erat dengan proses pengambilan keputusan pemilihan karier siswa. Siswa yang memiliki keyakinan di dalam dirinya bahwa keberhasilan karier di masa depannya dipengaruhi oleh pemilihan 
keputusan kariernya di saat sekarang, akan membuat siswa mengarahkan perilakunya untuk mempersiapkan proses pemilihan karier tersebut. Disamping itu, jika siswa mengambil keputusan pemilihan karier sesuai dengan peran jenisnya, maka akan mendapatkan dukungan yang positif dari lingkungan sekitarnya.

Berdasarkan latar belakang masalah yang telah diuraikan tersebut penelitian ini dilakukan dengan tujuan untuk menguji secara empiris tentang: (1) hubungan Locus of Control dengan keputusan pemilihan karier siswa kelas X, (2) hubungan persepsi peran jenis dengan keputusan pemilihan karier siswa kelas X, (3) hubungan Locus of Control dan persepsi peran jenis kelamin dengan keputusan pemilihan karier siswa kelas X, (4) perbedaan keputusan pemilihan karier siswa kelas X ditinjau dari Locus of Control, (5) perbedaan keputusan pemilihan karier siswa kelas X ditinjau dari persepsi peran jenis kelamin.

Hasil penelitian ini diharapkan dapat memberikan sumbangan yang berguna bagi pengembangan ilmu bimbingan dan konseling, khususnya bimbingan dan konseling karier.

\section{Metode Penelitian}

Penelitian menggunakan pendekatan kuantitatif-non eksperimental. Penelitian ini akan meneliti hubungan sebab-akibat yang tidak dimanipulasi atau diberi perlakuan oleh peneliti maka jenis penelitian ini termasuk penelitian expost-facto (Sukmadinata, 2009: 55).

penelitian ini menggunakan tiga macam Variabel yaitu dua variabel bebas (dependent), yaitu variabel bebas pertama (X1) yang diprediksi memiliki hubungan dengan variabel Y, sedangkan X2 disebut pula variabel bebas kedua yang diprediksi memiliki hubungan dengan variabel Y. Sedangkan variabel terikat (independent) diberi simbol Y.

Variabel bebas pertama dalam penelitian ini adalah locus of control dan variabel bebas keduanya adalah persepsi peran jenis kelamin. Variabel terikat adalah keputusan pemilihan karier. Locus of control merupakan faktor internal yang diprediksi mempengaruhi keputusan pemilihan karier siswa, sedangkan persepsi peran jenis kelamin merupakan sebuah cara pandang perilaku 
individu terhadap pola aturan perilaku laki-laki dan perempuan yang merupakan hasil interaksi individu dengan lingkungan sosialnya.

Populasi dalam penelitian ini adalah siswa kelas X di SMA Negeri 6 Semarang tahun ajaran 2009/2010. Jumlah siswa sebanyak 355 siswa. Sampel yang diambil dalam penelitian ini adalah 186 siswa. Pengambilan sampel penelitian ini dilakukan melalui dua tahap. Tahap pertama dilakukan dengan melakukan undian terhadap 10 kelas yang ada hingga diperoleh 6 kelas yang akan dijadikan sebagai sampel area. Sampel area diambil sebanyak enam kelas untuk memenuhi jumlah sampel penelitian yang dibutuhkan, yaitu sejumlah 186 siswa. Tahap kedua dilakukan dengan melakukan undian kepada seluruh populasi sesuai dengan kelas masing-masing tanpa pengembalian sehingga diperoleh jumlah sampel sebanyak 186 siswa. Berdasarkan penentuan ukuran sampel dengan menggunakan tabel Krejcie yang mendasarkan pengambilan subyek secara proporsional, sehingga untuk mencapai jumlah sampel sebanyak 186 siswa dari 6 kelas yang telah dipilih sebagai sampel area, setiap kelas diambil 31 orang sebagai sampel.

Metode pengumpulan data pada penelitian ini menggunakan tiga instrumen, yaitu:

\section{Skala Pemilihan Karier}

Skala ini disusun berdasarkan modifikasi terhadap Holland Occupational Themes. Skala disusun berdasarkan enam orientasi kepribadian, yang dilihat dari sudut pandang sifat, kemampuan dan kegemaran terhadap suatu bidang karier tertentu.

\section{Skala Locus of Control}

Metode pengumpulan data aspek locus of control di lakukan dengan menggunakan skala locus of control. Skala tersebut untuk mengukur internal dan external locus of control.

Skala locus of control penyusunannya menggunakan butir-butir pernyataan jenis tertutup dan bersifat obyektif. Skala Likert digunakan sebagai bentuk respon responden terhadap pernyataanpernyataan yang disusun. Penyusunan dan pengembangan butirnya didasarkan pada teori Fournier, Jeanrie, \& Drapeau (1996) dalam Lopez dan Snyder (2003: 146).

3. Skala Persepsi Peran Jenis Kelamin 
Skala pengukuran psikologis yang berupa skala sikap digunakan untuk mengungkap persepsi peran jenis kelamin pada siswa kelas X SMA. Skala akan diisi oleh responden.

Skala persepsi peran jenis kelamin penyusunannya menggunakan butir-butir pernyataan jenis tertutup dan bersifat obyektif. Skala Likert digunakan sebagai bentuk respons responden terhadap pernyataan-pernyataan yang disusun. Penyusunan dan pengembangan butirnya didasarkan pada teori-teori yang telah ada.

Sebelum melakukan penelitian, terlebih dahulu dilakukan uji coba alat ukur dengan tujuan untuk mengetahui apakah alat ukur mampu menghasilkan data yang akurat sesuai dengan tujuan ukurnya. Data uji coba digunakan untuk menghitung daya beda aitem dan reliabilitas alat ukur.

Pengambilan data uji coba skala keputusan pemilihan karier, locus of control dan persepsi peran jenis kelamin dikenakan kepada 33 orang siswa kelas X SMA Negeri 6 Semarang. Pengambilan subjek uji coba dilakukan dengan teknik Quota Sampling.

Data yang diperoleh dari uji coba alat ukur akan diperoleh estimasi validitas datanya dengan menggunakan pengujian terhadap isi skala melalui analisis rasional atau Professional Judgement dan estimasi reliabilitasnya menggunakan teknik koefisien reliabilitas Alpha Cronbach.

Hasil analisis reliabilitas yang dilakukan terhadap 63 aitem skala keputusan pemilihan karier, terdapat 30 aitem valid dan 33 aitem gugur dengan menggunakan korelasi aitem total 0,3 dan taraf signifikansi 5\%. Berdasarkan 30 aitem yang valid diperoleh koefisien korelasi aitem total terkoreksi berkisar antara 0,306-0,624. Hasil analisis reliabilitas menghasilkan koefisien Alpha sebesar 0,788 .

Hasil analisis reliabilitas yang dilakukan terhadap 59 aitem skala locus of control, terdapat 25 aitem valid dan 34 aitem gugur dengan menggunakan korelasi aitem total 0,3 dan taraf signifikansi 5\%. Berdasarkan 25 aitem yang valid diperoleh koefisien korelasi aitem total terkoreksi berkisar antara 0,304-0,498. Hasil analisis reliabilitas menghasilkan koefisien Alpha sebesar 0,680.

Hasil analisis reliabilitas yang dilakukan terhadap 59 aitem skala persepsi peran jenis kelamin, terdapat 35 aitem valid dan 24 aitem gugur dengan menggunakan korelasi aitem total 0,3 
dan taraf signifikansi 5\%. Berdasarkan 35 aitem yang valid diperoleh koefisien korelasi aitem total terkoreksi berkisar antara 0,302-0,650. Hasil analisis reliabilitas menghasilkan koefisien Alpha sebesar 0,827 .

Data yang terkumpul dari lapangan, akan di analisis menggunakan analisis regresi untuk mengetahui ada tidaknya pengaruh antar variabel. Data yang diperoleh dari skala penelitian terlebih dahulu dilakukan uji asumsi sebagai syarat untuk dapat dilakukan uji hipotesis. Uji asumsi tersebut meliputi: (1) uji normalitas, (2) uji linearitas, (3) uji homogenitas, (4) uji heteroskedastisitas, dan (5) uji multikolinearitas.

\section{Hasil Penelitian}

1. Keputusan Pemilihan Karier

Deskripsi Siswa Pada Skala Keputusan Pemilihan Karier

\begin{tabular}{|c|l|c|c|c|c|}
\hline \multirow{2}{*}{ No } & \multirow{2}{*}{ Pemilihan Karier } & \multicolumn{3}{|c|}{ Jumlah Siswa } & \multirow{2}{*}{ Persentase } \\
\cline { 3 - 6 } & & Laki-laki & Perempuan & Total & \\
\hline 1 & Realistik & 8 & 7 & 15 & $8,06 \%$ \\
\hline 2 & Investigatif & 9 & 4 & 13 & $6,99 \%$ \\
\hline 3 & Artistik & 14 & 15 & 29 & $15,59 \%$ \\
\hline 4 & Sosial & 23 & 22 & 45 & $24,19 \%$ \\
\hline 5 & Enterprising & 17 & 15 & 32 & $17,20 \%$ \\
\hline 6 & Konvensional & 11 & 6 & 17 & $9,14 \%$ \\
\hline 7 & Kombinasi & 10 & 25 & 35 & $18,82 \%$ \\
\hline
\end{tabular}

2. Locus of Control

Deskripsi Siswa Pada Skala Locus of Control

\begin{tabular}{|c|c|c|c|c|c|}
\hline \multirow{2}{*}{ No } & \multirow{2}{*}{ Tipe Locus of Control } & \multicolumn{3}{|c|}{ Jumlah Siswa } & \multirow{2}{*}{ Persentase } \\
\cline { 3 - 6 } & & Laki-laki & Perempuan & Total & \\
\hline 1 & Internal Locus of Control & 81 & 86 & 167 & $89,78 \%$ \\
\hline 2 & External Locus of Control & 11 & 8 & 19 & $10,22 \%$ \\
\hline & TOTAL & 92 & 94 & 186 & $100 \%$ \\
\hline
\end{tabular}


3. Persepsi Peran Jenis Kelamin

Deskripsi Siswa Pada Skala Persepsi Peran Jenis Kelamin

\begin{tabular}{|c|l|c|c|c|c|}
\hline \multirow{2}{*}{ No } & \multirow{2}{*}{ Peran Jenis } & \multicolumn{3}{|c|}{ Jumlah Siswa } & \multirow{2}{*}{ Persentase } \\
\cline { 3 - 5 } & & Laki-laki & Perempuan & Total & \\
\hline 1 & Maskulin & 20 & 16 & 36 & $19,35 \%$ \\
\hline 2 & Feminin & 15 & 23 & 38 & $20,43 \%$ \\
\hline 3 & Androgini & 30 & 37 & 68 & $36,56 \%$ \\
\hline 4 & Undifferentiated & 27 & 18 & 44 & $23,66 \%$ \\
\hline & TOTAL & 92 & 94 & 186 & $100 \%$ \\
\hline
\end{tabular}

Sebelum dianalisis, data yang diperoleh terlebih dahulu diuji asumsi yang meliputi uji normalitas dan uji linearitas. Uji normalitas diperlukan untuk mengetahui normal tidaknya sebaran nilai variabel keputusan pemilihan karier, locus of control dan persepsi peran jenis kelamin. Uji linearitas dilakukan untuk mendapatkan hubungan antara variabel-variabel yang ada, sedangkan uji homogenitas dilakukan untuk mengetahui apakah variasi dalam kelompok adalah sama.

Uji normalitas terhadap sebaran skor variabel keputusan pemilihan karier diperoleh nilai Kolmogorov-Smirnov $\mathrm{Z}$ sebesar 0,663 dengan $\mathrm{p}=0,771$ ( $\mathrm{p}>0,05$; signifikan). Ini menunjukkan bahwa sebaran skor variabel keputusan pemilihan karier adalah normal. Hasil uji normalitas variabel locus of control diperoleh nilai Kolmogorof-Smirnov Z sebesar 0,650 dengan p = 0,791 ( $>>0,05$; signifikan). Ini menunjukkan bahwa sebaran skor variabel locus of control adalah normal. Uji normalitas terhadap skor variabel persepsi peran jenis kelamin juga diperoleh hasil sebaran normal dengan ditunjukkan oleh nilai Kolmogorof-Smirnov $\mathrm{Z}$ sebesar 0,837 dengan $\mathrm{p}=0,486$ ( $>0,05$; signifikan).

Hasil uji linearitas hubungan antara locus of control dan persepsi peran jenis kelamin terhadap keputusan pemilihan karier diperoleh nilai $\mathrm{F}$ linear sebesar 46,921 dan signifikansi 0,000 ( $\mathrm{p}<0,01$; signifikan). Hasil tersebut menunjukkan bahwa hubungan antara locus of control dan persepsi peran jenis kelamin terhadap keputusan pemilihan karier adalah linear.

Langkah selanjutnya adalah melakukan uji hipotesis.

1. Hubungan Locus of Control dengan Keputusan Pemilihan Karier 
Berdasarkan uji analisis regresi diperoleh nilai Standarized Beta sebesar 0,296 dengan taraf signifikansi 0,000 ( $\mathrm{p}<0,05$; signifikan), berarti ada hubungan yang signifikan antara locus of control dengan keputusan pemilihan karier.

2. Hubungan Persepsi Peran Jenis Kelamin dengan Keputusan Pemilihan Karier

Berdasarkan uji analisis regresi diperoleh nilai Standardized Beta 0,568 dengan taraf signifikansi $0,000(\mathrm{p}<0,05$; signifikan) menunjukkan ada hubungan yang signifikan antara persepsi peran jenis kelamin dengan keputusan pemilihan karier.

3. Hubungan Locus of Control dan Perseps Peran Jenis Kelamin dengan Keputusan Pemilihan Karier

Berdasarkan uji analisis regresi untuk mengetahui hubungan locus of control dan persepsi peran jenis kelamin terhadap keputusan pemilihan karier diperoleh nilai Standardized Beta variabel locus of control sebesar 0,132 dengan taraf signifikansi 0,038 ( $\mathrm{p}<0,05$; signifikan) menunjukkan ada hubungan yang signifikan antara locus of control dengan keputusan pemilihan karier. Nilai Standardized Beta variabel persepsi peran jenis kelamin sebesar 0,527 dengan taraf signifikansi 0,000 ( $\mathrm{p}<0,05$; signifikan) menunjukkan ada hubungan yang signifikan antara persepsi peran jenis kelamin dengan keputusan pemilihan karier. Berdasarkan perhitungan tersebut dapat dikatakan bahwa terdapat hubungan yang signifikan antara locus of control dan persepsi peran jenis kelamin dengan keputusan pemilihan karier. Hasil analisis regresi menunjukkan koefisien determinasi $\left(\mathrm{R}^{2}\right)$ sebesar 0,338 yang berarti $33,8 \%$ keputusan pemilihan karier dipengaruhi oleh locus of control dan persepsi peran jenis kelamin. Sedangkan sisanya sebesar 66,2\% dipengaruhi oleh variabel lain yang tidak diteliti dalam penelitian ini.

Analisis perbedaan persepsi peran jenis kelamin terhadap keputusan pemilihan karier dengan menggunakan Chi-Square menghasilkan $\chi^{2}=29,041$ dengan signifikansi 0,048 ( $\mathrm{p}<0,05$; signifikan) yang berarti terdapat perbedaan yang signifikan keputusan pemilihan karier pada siswa yang memiliki persepsi peran jenis kelamin maskulin, feminin, androgini 
dan undifferentiated. Selain itu dari hasil analisis juga diperoleh $\emptyset$ (contingency coefficient) $=0,367$ dengan taraf signifikansi 0,048 ( $\mathrm{p}<0,05$; signifikan) yang menunjukkan bahwa ada korelasi antara persepsi peran jenis kelamin dengan keputusan pemilihan karier.

\section{Pembahasan}

\section{Hubungan Locus of Control dengan Keputusan Pemilihan Karier}

Hasil penelitian dan analisis data menunjukkan bahwa terdapat hubungan yang signifikan antara locus of control dan keputusan pemilihan karier. Hal ini berarti bahwa jika dilihat secara umum, orientasi internal dan external locus of control siswa mempengaruhi pengambilan keputusan karier siswa. Sumbangan efektif locus of control terhadap keputusan pemilihan karier sebesar $8,8 \%$. Hasil analisis ini menunjukkan bahwa hipotesis dalam penelitian ini terbukti, yaitu terdapat hubungan locus of control dengan keputusan pemilihan karier.

Hasil penelitian ini sejalan dengan penelitian yang dilakukan oleh Zulkaida, dkk (2007) yang mendapatkan hasil bahwa Locus of Control memiliki pengaruh yang signifikan terhadap kematangan karier siswa SMA karena adanya keyakinan akan kemampuan diri dalam memilih karier yang disertai dengan keyakinan bahwa seluruh peristiwa dalam hidupnya ditentukan oleh usaha dan perilakunya sendiri.

Holland mengungkapkan bahwa proses pilihan karier individu tidak hanya terjadi satu kali seumur hidup, namun bisa terjadi berulangkali selama individu masih melakukan evaluasi kesesuaian antara faktor pribadi atau faktor internal didalam dirinya dengan karier yang dijalaninya (Sukardi, 2004: 93).

Super dalam Santrock (2008: 484) juga menekankan bahwa remaja yang memasuki usia 14 sampai 18 tahun berada pada tahap kristalisasi, yaitu periode proses kognitif untuk memformulasikan sebuah tujuan karier umum melalui kesadaran akan berbagai kemungkinan minat, nilai dan perencanaan karier. Konsekuensi dari tahap ini adalah bahwa siswa belum menentukan pilihan kariernya secara khusus kepada suatu bidang pilihan karier tertentu. Siswa baru 
menentukan arah pilihan kariernya kepada satu pilihan karier secara khusus jika telah memiliki keyakinan yang mantap tentang nilai hidup yang diyakininya.

2. Hubungan Persepsi Peran Jenis Kelamin dengan Keputusan Pemilihan Karier Siswa

Hasil penelitian dan analisis data menunjukkan bahwa terdapat hubungan yang signifikan antara persepsi peran jenis kelamin dengan keputusan pemilihan karier. Hal ini berarti bahwa persepsi siswa terhadap peran jenisnya berhubungan dengan pengambilan keputusan pemilihan kariernya. Sumbangan efektif hubungan persepsi peran jenis kelamin dengan pemilihan karier sebesar 32,3\%. Hasil analisis ini menunjukkan bahwa hipotesis dalam penelitian ini terbukti, yaitu terdapat hubungan persepsi peran jenis kelamin dengan keputusan pemilihan karier.

Hasil penelitian ini mendukung penelitian yang dilakukan oleh Correl (2001: 1691) yang menunjukkan bahwa keyakinan budaya tentang perbedaan persepsi gender mempengaruhi keputusan awal mengenai karier yang relevan bagi laki-laki dan perempuan. Keyakinan terhadap peran gender atau peran jenis akan menyebabkan perbedaan keputusan untuk memilih karier di bidang sains, matematika, atau bidang teknik.

Pengaruh yang ditunjukkan oleh persepsi peran jenis kelamin terhadap pemilihan karier siswa tidak dapat terlihat secara nyata dengan melihat hasil perhitungan statistik yang menunjukkan kecenderungan siswa yang berjenis kelamin perempuan cenderung memiliki peran jenis feminin, yang mengarahkan pilihan kariernya pada karier yang identik dengan sifat-sifat feminin yang lemah lembut, sebaliknya siswa yang berjenis kelamin laki-laki akan cenderung memilih karier yang identik dengan sifat-sifat maskulin yang kuat. Hasil analisis data hanya bisa menjelaskan pengaruh secara umum persepsi peran jenis kelamin terhadap pemilihan karier siswa tanpa memperhatikan persepsi peran jenis kelamin siswa laki-laki dan perempuan kepada kecenderungan peran jenis maskulin, feminin, androgini dan undifferentiated.

Hal tersebut diperkuat dengan pendapat Pleck (Santrock, 2003: 385) mengenai transendensi peran gender yang merujuk kepada suatu keyakinan bahwa ketika akan menilai kompetensi individu, maka penilaian hendaknya dilakukan bukan berdasarkan maskulinitas, feminimitas atau 
androginitas, melainkan lebih berdasarkan kepada kompetensi individu yang bersangkutan. Demikian juga ketika melakukan pemilihan karier, siswa tidak lagi memperhatikan dengan seksama mengenai peran jenisnya, namun lebih kepada menyesuaikan pilihan kariernya berdasarkan kepada kompetensi yang dimilikinya.

3. Hubungan Locus of Control dan Persepsi Peran Jenis Kelamin dengan Keputusan Pemilihan Karier Siswa

Hasil penelitian dan analisis data penelitian ini menunjukkan hasil terdapat hubungan locus of control dan persepsi peran jenis kelamin dengan pemilihan karier siswa. Sumbangan efektif hubungan locus of control dan persepsi peran jenis kelamin dengan pemilihan karier siswa sebesar 33,8\%. Hasil analisis ini menunjukkan bahwa hipotesis dalam penelitian ini terbukti, yaitu terdapat hubungan locus of control dan persepsi peran jenis kelamin dengan pemilihan karier siswa.

Pengaruh locus of control dan persepsi peran jenis kelamin terhadap pemilihan karier siswa dikarenakan kedua hal tersebut merupakan faktor internal yang mempengaruhi pengambilan keputusan karier siswa. Locus of control sebagai nilai hidup yang dianut individu merupakan perwujudan salah satu faktor internal di dalam diri siswa yang turut mempengaruhi pemilihan kariernya. Nilai-nilai kehidupan (values) yaitu ideal-ideal yang di kejar oleh individu dimana-mana dan kapan pun juga. Nilai-nilai menjadi pedoman dan pegangan dalam hidup dan sangat menentukan bagi gaya hidup seseorang (life style).

Persepsi peran jenis kelamin merupakan sebuah cara pandang perilaku yang didasarkan pada standar atau aturan pola perilaku bagi anggota jenis kelamin laki-laki dan perempuan yang disetujui dan diterima anggota kelompok sosial. Hal ini menunjukkan bahwa persepsi peran jenis kelamin merupakan salah satu aspek yang mempengaruhi pemilihan karier siswa di tinjau dari hubungan siswa dengan lingkungan sosial-budaya tempat individu di besarkan. Lingkungan ini luas sekali dan berpengaruh besar terhadap pandangan dalam banyak hal yang dipegang teguh oleh setiap keluarga, yang pada gilirannya ditanamkan pada anak-anak. Pandangan atau keyakinan ini mencakup 
gambaran tentang luhur rendahnya aneka jenis pekerjaan, peranan laki-laki dan perempuan dalam kehidupan masyarakat, dan cocok tidaknya jabatan tertentu untuk laki-laki dan perempuan.

Hal ini di dukung oleh penelitian yang dilakukan oleh Correl (2001: 1691) yang menunjukkan hasil bahwa keyakinan budaya tentang perbedaan persepsi gender mempengaruhi keputusan awal mengenai karier yang relevan bagi laki-laki dan perempuan. Keyakinan budaya tentang jenis kelamin berpendapat mengenai bias persepsi individu terhadap kompetensi mereka di berbagai tugas karir yang relevan dalam mengontrol kemampuan aktualnya. Jika individu bertindak atas persepsi perbedaan gender ketika membuat keputusan karir, keyakinan budaya tentang gender secara substansial membedakan arah karir laki-laki dan perempuan.

\section{Kesimpulan dan Saran}

Kesimpulan yang dapat diambil berdasarkan hasil penelitian dan pengujian hipotesis diperoleh hasil sebagai berikut: (1) Ada hubungan yang signifikan antara Locus of control dengan keputusan pemilihan karier siswa, (2) Ada hubungan yang signifikan antara persepsi peran jenis kelamin dengan keputusan pemilihan karier siswa, (3) Ada hubungan yang signifikan antara Locus of control dan persepsi peran jenis kelamin dengan keputusan pemilihan karier siswa, yang berarti bahwa keyakinan individu terhadap peristiwa-peristiwa yang terjadi di dalam hidupnya dan cara pandang perilaku siswa terhadap pola perilaku maskulin, feminin, androgini dan undifferentiated mempengaruhi pengambilan keputusan karier siswa, (4) Siswa yang memiliki internal locus of control memiliki pilihan karier yang tidak berbeda dengan siswa yang memiliki external locus of control, (5) Terdapat perbedaan pemilihan karier siswa yang memiliki peran jenis maskulin, feminin, androgini atau undifferentiated. Namun demikian, tidak terlihat pengelompokan secara jelas kepada jenis pekerjaan tipe realistik, investigatif, artistik, sosial, enterprising atau konvensional.

Berdasarkan hasil penelitian yang telah dilakukan, ada beberapa saran yang dapat diberikan kepada pihak-pihak terkait, yaitu: (1) Konselor diharapkan dapat membantu siswa memberikan 
motivasi kepada siswa untuk meningkatkan kreatifitas, imajinasi, dan harapan dengan memperhatikan etika dan norma-norma kehidupan dalam mengarahkan perilakunya menuju persiapan pengambilan keputusan karier, (2) peneliti selanjutnya memperhatikan faktor lain yang dipandang berpengaruh tetapi belum disertakan dalam penelitian ini seperti faktor internal, yaitu kemampuan khusus dan pengalaman belajar yang dimiliki oleh siswa. Faktor eksternal yang dapat diperhatikan adalah kelas sosial siswa serta kondisi dan peristiwa lingkungan, seperti kesempatan kerja dan pelatihan yang dapat diperoleh siswa.

\section{Daftar Pustaka}

Analisa Upah, Locus of Control dan Perilaku Kerja Pekerja PT. Trisakti Cipta Nusantara. http://digilib.petra.ac.id

Azwar, S. 2003. Penyusunan Skala Psikologis. Edisi 1. Yogyakarta: Pustaka Pelajar

-------. 2004. Reliabilitas dan Validitas. Yogyakarta : Pustaka Pelajar

Brown, D. 2002. Career Choice and Development. Fourth Edition. San Fransisco: Jossey-Bass 2007. Career Information, Career Counseling, and Career Development. Ninth Edition. Boston: Pearson Education, Inc

Correl, S. J. 2001. Gender and the Career Choice Process: The Role of Biased Self-Assessments. American Journal of Sociology Volume 106 Number 6 (May 2001): 1691-1730

Graham, J. R. \& Lilly, R. S. 1984. Psychological Testing. New Jersey: Prentice-Hall, Inc

Hirschi, A \& Lage, D. 2007. The Relation of Secondary Students' Career-Choice Readiness to a Six-Phase Model of Career Decision Making. Journal of Career Development Volume 34 Number 2. December 2007, h. 164-191

Hurlock, E. B. 1999. Perkembangan Anak Jilid 2. Edisi ke enam. Alih Bahasa: dr. Med. Meitasari Tjandrasa. Jakarta: Erlangga

Lopez, S. J \& Snyder, C. R. 2003. Positive Psychological Assessment: A Handbook of Models and Measures. Washington DC: American Psychological Association

Munandir. 1996. Program Bimbingan Karier di Sekolah. Jakarta: Dirjen Dikti Depdikbud

Phares, E.J. 1976. Locus of Control in Personality. Canada: Silver Burdett Company

Santrock, J. W. 2008. Adolesence Perkembangan Remaja. Edisi ke-enam. Alih Bahasa: Drs. Shinto B. Adelar, M. Sc dan Sherly Saragih, S. Psi. Jakarta: Elangga 
Sukardi, D. K. 1994. Bimbingan Karier di Sekolah-Sekolah. Edisi Revisi. Jakarta: Ghalia Indonesia

Sukardi, D. K. 2004. Psikologi Pemilihan Karier. Jakarta: Rineka Cipta

Sukmadinata, N.S. 2009. Metode Penelitian Pendidikan. Bandung: PT. Remaja Rosdakarya

Winkel, W.S \& Hastuti, S. 2007. Bimbingan dan Konseling di Institusi Pendidikan. Edisi Revisi. Yogyakarta: Media Abadi

Zulkaida, A.,dkk. 2007. Pengaruh Locus of Control dan Efikasi Diri terhadap Kematangan Karier Siswa Sekolah Menengah Atas (SMA). Proceeding PESAT. Vol. 2. 21-22 Agustus 2007 